\title{
Integrated Management of Entrepreneurship Education in Tridharma of Higher Education (Case study at Pancasakti Tegal University and IKIP Veteran Semarang)
}

\author{
Faridah $^{1}$, Neni Hendaryati ${ }^{2}$, A.Rony Yulianto ${ }^{3}$ \\ Pancasakti University, Halmahera street KM. 01 Tegal City ${ }^{1,2,3}$ \\ \{faridahwiwoho@gmail.com¹,neni.hendaryati@upstegal.ac.id², roneyuli@gmail.com³
}

\begin{abstract}
This study aims to analyze management of entrepreneurship education for students, empirical model analysis of entrepreneurship education management for students, tri dharma integrated entrepreneurship education management model for students, and the effectiveness of tri dharma integrated entrepreneurship education management model for the formation of student entrepreneurial attitudes with the literature review and research development. This study is expected to show the importance of the commitment of universities to cultivate entrepreneurship; all management functions of entrepreneurship education at the university, faculty, and study program level should be focused on the integration of entrepreneurship education programs and activities in higher education tri dharma; the application of this model does not exclude various entrepreneurship program schemes organized by the Ministry of Research and Higher Education, and it can use a validated guidebook in this study as an implementation guide. So that it can improve entrepreneurial quality in accordance with the ideals of the university.
\end{abstract}

Keywords: Entrepreneurship Education, Integrated Management, Tridharma

\section{Introduction}

One important implication regarding the global competition constellation and the national policy issue of higher education is the need for the development of entrepreneurial oriented tertiary institutions and university graduates who are entrepreneurial competent [1]N. P. Low, 1984). In this industrial revolution era, all data operations have used digital data [2]. Then, every university is expected to prepare all available resources including basic academic resources and human resources. The urgency of the development of tertiary institutions oriented towards the formation of entrepreneurial attitudes [3] graduates has been a commitment of most Indonesian Private Universities. Devices component of higher education system based on the analysis model of the position of the education system consisting of [4]: (1) the purpose of higher education; (2) the threshold requirements for implementing higher education; (3) input; (4) process; (5) the results and impact of the education process; and (6) parties with an interest in the university system. Tools for 
performance indicators can be formulated in the form of: (1) efficiency; (2) productivity; (3) effectiveness; (4) accountability; (5) relevance; (6) adaptability; and (7) the academic atmosphere in higher education. What underlies the management of education in increasing entrepreneurship in a high performance is one of the difficulties on opportunities for employment. There are a number of problems faced by universities in the framework of implementing entrepreneurship in the existing curriculum; entrepreneurial vision has not been used as a basic value and it is a reference for all parties to prepare universities graduates. This brings the confusion of students to practice entrepreneurship after completing their studies [5]; teaching entrepreneurship tends to be more oriented to theoretical philosophical understanding so that it does not provide learning experiences [6] that are oriented towards developing attitudes and skills and entrepreneurial education has not been integrally organized and accommodated in implementation of tridarma of higher education so that it is not optimal in achieving competency in student entrepreneurial attitudes [7]. Almost all universities in Indonesia still apply output-oriented curriculum that is not focused on the field to be achieved. The implementation of the tri dharma tertiary institution is a mutually integrated among students, lecturers, universities and the government and industries around it. This can be used as a series of collaborations in the form of partners abbreviated as $\mathrm{ABG}$ (academic to business government) [8]. As for universities that want to realize an entrepreneurial vision, it is very important to condition themselves as learning organizations, namely learning organizations which refers to as organizations in creating, acquiring and transferring new knowledge and views, and experts in changing behavior to reflect these new knowledge and views.

\section{Literature Review}

Some empirical studies influence of entrepreneurship education programs in universities on their interesting assumptions and the possibility of new businesses [9]. A literature review of entrepreneurship and business education and entrepreneurship programs proves that these programs encourage entrepreneurs to start their businesses. Education has a strong positive influence on entrepreneurship in realizing the ability to work independently and the success of graduates themselves. Experience also has the same relationship even though it is not as strong as education [10]. The different theoretical underpinnings of entrepreneurship education are also highlighted that suggest a need to think in new directions about possible future pedagogical [11]. That entrepreneurship and business education has grown in various countries, as a method for developing entrepreneurial culture, creating new businesses, increasing entrepreneurship and forming entrepreneurial mindset through education and learning. In entrepreneurship education programs not only provide theoretical knowledge, but guarantee the development of entrepreneurial mindset in graduates, through the formation of entrepreneurial skills, behaviors and attitudes becoming the key to competence and enable them to become entrepreneurs. Many countries are increasingly recognising entrepreneurship as an effective means of creating jobs; increasing productivity and competitiveness; and improving the quality of life and achieving community goals [12]. For this reason, cooperation and contribution of various parties are needed in achieving the success of the goals and objectives of entrepreneurship education.

In entrepreneurship context, an attitude has been defined as the extent to which one perceives entrepreneurial behaviour and its consequences as valuable, beneficial and 
favourable [13]. There are four aspects of an entrepreneurial attitude, that is: (a) need for achievement, (b) personal control over behaviour, (c) innovation, and (d) self-esteem [14].

[15] said that integration deeper integration of extra-curricular activitie and entrepreneurship education on management education curricula is crucial for the development of dynamic managerial capabilities. The capability approach within the framework of entrepreneurial programs can strengthen individual modalities achieved through a variety of programs for understanding social and economic contexts [16] [17]. All of it has a special effect on young people in realizing themselves as entrepreneurs. Regarding entrepreneurship, business education entrepreneurship programs prove that these programs encourage entrepreneurs to start their business.

[18] research "Adopting Strategic Management in Planning and Implementation of Entrepreneurship Education in Tertiary Institutions in Nigeria" confirms that entrepreneurial education programs not only provide theoretical knowledge, but guarantee the development of an entrepreneurial mindset in graduates, through skill building. entrepreneurship, behavior and attitudes, which are the key competencies and enable them to become entrepreneurs. Entrepreneurship education is important, especially at the university level. Average of entrepreneurship education in UPI shows that entrepreneurship education indicators is $70.03 \%$ say agree, $82.13 \%$ consisted of 24 students who strongly agree and agree with the concept of entrepreneurial intentions while $46.30 \%$ is composed of 13 students who agree and disagree with the rest answering entrepreneurial development [19][20]. [21] states that Kirkpatrick's program evaluation model showed that the entrepreneurship awareness camp significantly enhanced the entrepreneurial culture among the youth.

\section{Methodology / Materials}

The relevance of Entrepreneurship Education in Higher Education "concludes that the disinterest in student entrepreneurship is caused by three factors [22]: (1) mindset problems. Many scholars still think of being job seekers, not job creators; (2) issues of entrepreneurship curriculum that are inadequate in quantity and quality; (3) lack of seriousness in creating entrepreneurs from among students. The mission of higher education consists of three main mission of higher education, which refers to the aspects of acquisition, transmission and application. The reach of education management includes the macro and micro levels with distinctive activities in accordance with the characteristics of educational organizations. The results of the implementation of education management are the success of education grouped into three aspects, namely: (a) achievement, with equitable input indicators, a large number of graduates, high quality graduates, and high relevance; (b) atmosphere, which includes enthusiasm for learning, high morale, and trust from various parties; and (c) economy, both in terms of operations and income, learning perspective, which comprehends attitudes through learning and reinforcement theory, incentive theory, and theories of cognitive consistency. The formation of attitudes is also an integral part of the concept of taxonomy of educational goals. Then, the purpose of education is divided into three domains, namely: (1) cognitive domain (2) affective domain and (3) psychomotor domain. 


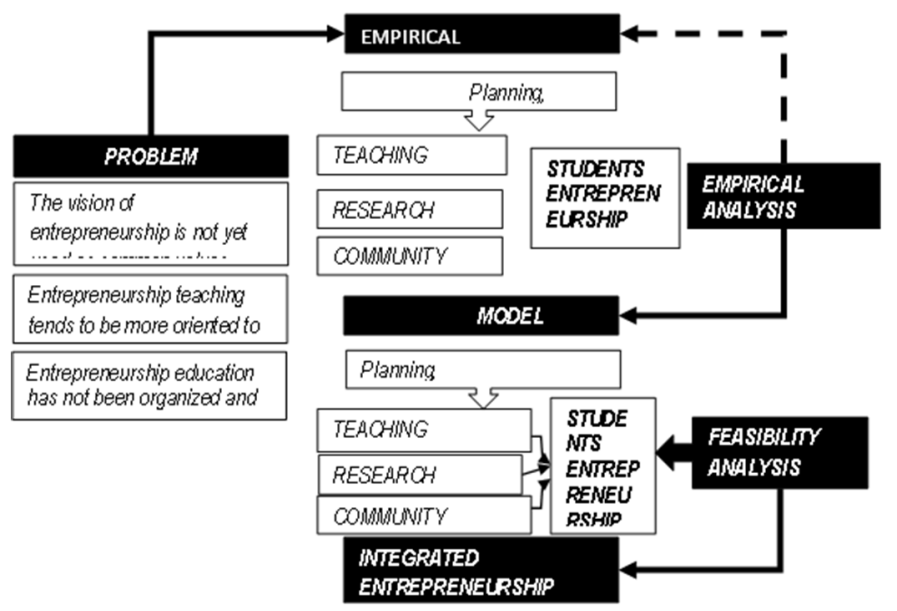

Fig. 1. Research Framework and Development of

Management Model of Entrepreneurship Education in PrivateUniversities

Briefly, the picture above explains that there are entrepreneurial problems that exist in higher education which are then held empirically to implement Tri Dharma which consists of teaching, research and community service to provide solutions to students in the form of entrepreneurial concepts. Based on problems that exist to the final model in the form of this guidebook will be given to students. In developing the entrepreneurship model, it is divided into 3 (three) groups, namely, preliminary studies, then model development and model validation. In its implementation, students must know what business will be carried out by describing the needs analysis, then developing existing concepts by evaluating and improving to produce the appropriate model and the final stage is to build an integrated business model in several scopes starting from a limited scope on a regular basis.

\section{Results and Discussion}

The feasibility of the model from this aspect is related to the ease of lecturers to fulfill the quality of the elements in the process of entrepreneurship learning which relates to the results of classroom observations and reviews of learning device documents. The data informs that the management aspects of entrepreneurship learning carried out by collaborator lecturers of this study is generally well categorized. The aspects in question are goals, lecture materials, methods, evaluations, and assessment components. The final model can be said to be effective in terms of achieving the quality elements of the learning process that can be done by the lecturer. The data shows that after student respondents examined the guidebook for implementing the management model of entrepreneurship education, especially management of learning activities, they predicted the goodness of the eight learning indicators. If the perception score of all (39 respondents) students from two private universities for all these indicators is calculated based on a scale, then the quality of learning entrepreneurship courses in the final model is categorized (predicted) both by student respondents in the two study programs studied. In other words, if the integrated entrepreneurship education management model is implemented, the aspects of student learning satisfaction are predicted to be better than the empirical models that have been taking place in the two study programs studied. It is 
grouped into aspects of student leadership, student personal management, and personal assessment of students. The analysis results show:

a. There is a difference in the average score of student leadership before and after the trial of the implementation of an integrated entrepreneurship education management model, which is equal to 1.91 (obtained from a reduction in scores before 5.12 with a score after 7.03); standard deviation 4.24; probability or Sig $0.00=0.00 \%<5 \%$. The decision on the results of the test explains that the management model of integrated entrepreneurship education is effective in improving student business entrepreneurial attitudes, aspects of student leadership.

b. There is a difference in the average score of the students' personal management aspects before and after the trial implementation of the integrated entrepreneurship education management model of 1.93 (obtained from the reduction in the pretest score 4.97 with the first post-test score 6.91; standard deviation 4.94; probability or Sig value $0.00=$ $0.00 \%<5 \%$. In other words, the application of an integrated entrepreneurship education management model effectively enhances student entrepreneurial attitudes to the aspects of personal management of students.

c. There is a difference in the average score of aspects of personal assessment of students after and before the trial of the application of the model is 1.92 (6.97 minus 5.05); standard deviation 3.90; probability or Sig $0.00=0.00 \%<5 \%$. The figures inform that the application of an integrated entrepreneurship education management model effectively enhances student entrepreneurial attitudes towards the personal aspects of student assessment.

The integrated management model of entrepreneurship education is carried out through classroom learning, research, and community service which are overall designed according to the ability of the study program. This is based on the Law on Higher Education Number 12 of 2012, Article 1 which explains that: Tridharma of Higher Education is the obligation of Higher Education to carry out education, research, and community service (paragraph 9). Ideally, the three higher education tridharmas work together. Colleges must not only fulfill a portion of dharma and deny others. Therefore, balancing the third implementation portion of the dharma is very important. Entrepreneurial attitudes include aspects of leadership, personal judgment, and personal management. Leadership shows honesty and integrity; responsible behavior; initiative; other efforts; lead others by using positive statements; develop team spirit; involve other people in working towards a shared vision; share authority if needed; appreciate the value of diversity. The results of the research conducted it supports the theory stated by [13] that four aspects of entrepreneurial attitudes can be effective if integrated entrepreneurship education management is carried out properly.

\section{Conclusion}

Based on the results of research entrepreneurship education management models conclusions can be drawn as follows.

a. Management of entrepreneurship education in Economic Education Study Programs in the PTS studied includes functions of planning, organizing, staff development, direction, and supervision.

b. The empirical condition of entrepreneurship education management in the Economic Education study program in PTS is characterized by an incompatible entrepreneurial 
vision with its implementation, and the lack of integration of entrepreneurship education in the activities of the tertiary tridarma.

c. The entrepreneurial education management model developed in this study is an alternative model that has a fundamental difference compared to the upper empirical model. The distinguishing element lies in the integration between learning, research, and service to an entrepreneurial society.

d. The integrated management model of entrepreneurship education is effective seen from the improvement of the quality of the process of learning, research, and community service in the field of entrepreneurship at the study program level. In addition, limited trials on students showed that the management model of entrepreneurship education was integrated effectively in improving the dimensions of leadership, personal management, and personal assessment of students as a reflection of student entrepreneurial attitudes.

\section{References}

[1] T. Altenburg, H. Schmitz, and A. Stamm, "Breakthrough? China's and India's Transition from Production to Innovation," World Dev., vol. 36, no. 2, pp. 325-344, 2008, doi: 10.1016/j.worlddev.2007.06.011.

[2] S. V. Buer, G. I. Fragapane, and J. O. Strandhagen, "The Data-Driven Process Improvement Cycle: Using Digitalization for Continuous Improvement," IFACPapersOnLine, vol. 51, no. 11, pp. 1035-1040, 2018, doi: 10.1016/j.ifacol.2018.08.471.

[3] E. Kusakabe, "Advancing sustainable development at the local level: The case of machizukuri in Japanese cities," Prog. Plann., vol. 80, no. 1, pp. 1-65, 2013, doi: 10.1016/j.progress.2012.06.001.

[4] P. Van Der Heiden, C. Pohl, S. Bin Mansor, and J. Van Genderen, "The role of education and training in absorptive capacity of international technology transfer in the aerospace sector," Prog. Aerosp. Sci., vol. 76, pp. 42-54, 2015, doi: 10.1016/j.paerosci.2015.05.003.

[5] D. Lin, W. Zheng, J. Lu, X. Liu, and M. Wright, "Forgotten or not? Home country embeddedness and returnee entrepreneurship," J. World Bus., vol. 54, no. 1, pp. 1-13, 2019, doi: 10.1016/j.jwb.2018.08.003.

[6] P. Seuneke and B. B. Bock, "Exploring the roles of women in the development of multifunctional entrepreneurship on family farms: An entrepreneurial learning approach,” NJAS - Wageningen J. Life Sci., vol. 74-75, pp. 41-50, 2015, doi: 10.1016/j.njas.2015.07.001.

[7] M. Nurdin, "Center of Technology (COT) for Industrial Product Development through Collaboration and Partnership in Polytechnic Education," Procedia - Soc. Behav. Sci., vol. 52, pp. 207-216, 2012, doi: 10.1016/j.sbspro.2012.09.457.

[8] C. Bazan, "'From lab bench to store shelves:' A translational research \& development framework for linking university science and engineering research to commercial outcomes," J. Eng. Technol. Manag. - JET-M, vol. 53, no. December 2017, pp. 1-18, 2019, doi: 10.1016/j.jengtecman.2019.05.001.

[9] H. Bergmann, M. Geissler, C. Hundt, and B. Grave, "The climate for entrepreneurship at higher education institutions," Res. Policy, vol. 47, no. 4, pp. 700-716, 2018, doi: 10.1016/j.respol.2018.01.018.

[10] T. Fernandes and T. Pinto, "Relationship quality determinants and outcomes in retail 
banking services: The role of customer experience," J. Retail. Consum. Serv., vol. 50, no. May, pp. 30-41, 2019, doi: 10.1016/j.jretconser.2019.01.018.

[11] V. Ratten and P. Jones, "Entrepreneurship and management education: Exploring trends and gaps," Int. J. Manag. Educ., no. xxxx, p. 100431, 2020, doi: 10.1016/j.ijme.2020.100431.

[12] R. K. Jena, "Measuring the impact of business management Student's attitude towards entrepreneurship education on entrepreneurial intention: A case study," Comput. Human Behav., vol. 107, no. January, p. 106275, 2020, doi: 10.1016/j.chb.2020.106275.

[13] I. Ajzen, "Perceived behavioral control, self-efficacy, locus of control, and the theory of planned behavior," J. Appl. Soc. Psychol., vol. 32, no. 4, pp. 665-683, 2002, doi: 10.1111/j.1559-1816.2002.tb00236.x.

[14] D. Fenech, R., Priya, B., \& Ivanov, "Enterepreneurial attitudes, self efficacy and subjective norms amongst female Emirati Enterpreneurs," Int. J. Entrep., vol. 23, no. 1, pp. 1-11, 2019.

[15] J. Almeida, A. D. Daniel, and C. Figueiredo, "The future of management education: The role of entrepreneurship education and junior enterprises," Int. J. Manag. Educ., no. November 2018, p. 100318, 2019, doi: 10.1016/j.ijme.2019.100318.

[16] H. Etzkowitz, "Innovation Lodestar: The entrepreneurial university in a stellar knowledge firmament," Technol. Forecast. Soc. Change, vol. 123, no. 4, pp. 122-129, 2017, doi: 10.1016/j.techfore.2016.04.026.

[17] E. Muralidharan and S. Pathak, "Informal institutions and international entrepreneurship," Int. Bus. Rev., vol. 26, no. 2, pp. 288-302, 2017, doi: 10.1016/j.ibusrev.2016.07.006.

[18] C. and Friday's, "Adopting Strategic Management in Planning and Implementation of Entrepreneurship Education in Tertiary Institutions in Nigeria," 2013.

[19] Y. Rahmawati ES and I. Harta, "Keefektifan Pendekatan Open-Ended Dan Ctl Ditinjau Dari Hasil Belajar Kognitif Dan Afektif," J. Ris. Pendidik. Mat., vol. 1, no. 1, p. 113, 2014, doi: 10.21831/jrpm.v1i1.2669.

[20] K. E. Education, "Analisis Faktor-Faktor Yang Mempengaruhi Pendidikan Kewirausahaan(Entrepreneurship Education) Di Perguruan Tinggi Negeri Kota Bandung," SOSIO-DIDAKTIKA Soc. Sci. Educ. J., vol. 1, no. 1, pp. 47-53, 2018, doi: 10.15408/sd.v1i1.9522.

[21] T. Sakthi and A. A. M. Moshi, "Effectiveness measurement study on entrepreneurship awareness camp for technical education students using Kirkpatrick's model," Mater. Today Proc., no. xxxx, 2020, doi: 10.1016/j.matpr.2020.08.419.

[22] C. G. Iwu et al., "Entrepreneurship education, curriculum and lecturer-competency as antecedents of student entrepreneurial intention," Int. J. Manag. Educ., no. August 2018, p. 100295, 2019, doi: 10.1016/j.ijme.2019.03.007. 